'A man of violent and ungovernable temper': can fiction fill silences in the archives?

Katherine E Collins

The Oxford Centre for Life-Writing, University of Oxford, Oxford, UK

Wolfson College, Linton Road, Oxford OX2 6UD

Katherine.Collins@wolfson.ox.ac.uk

https://orcid.org/0000-0001-5333-7377

@aliceinacademia 


\section{'A man of violent and ungovernable temper': can fiction fill silences in the archives?}

Biofiction can be defined as fiction about a named, real person and is characterised by creativity, invention, and imaginative exploration. In this essay I deploy a mixture of nonlinear narrative and theoretical writing to explore the argument that creative ways of responding to archival silences illuminate, and also complicate, our attempts to recover women's lives from obscurity. As the text evolves, the narrative sections become more invented, more experimental, something more like fiction.

Keywords: Biofiction; Autofiction; Fiction; Women's Lives

Maggie had written the story of the beginning over and over. The day when her granddaughter, Emily, had flatly refused to bring a coat, so Eve's big cream scarf was wrapped around the nine-year-old girl like one of those crossover beach dresses advertised in the glossy magazines that come with Saturday newspapers. It reminded her of the day she had tried to help Eve learn for herself why sensible people brought coats with them on cold days - unpleasantly bulky around their arms though they may be - by allowing her to walk to school without one, one freezing February morning. She doubted Eve would even remember it, but it made Maggie smile to think of her finally seeing things from her mother's point of view, thirty years later.

Their usual café was full, so they walked back along the high street hoping somewhere else would have room. Nearly at the end of the row of shops they tried a tiny side street, the last possibility. And there they found a row of little windows painted 
in that grey-apple-green that ex-Londoners like to use for the woodwork on their restored cottages. The Milkshake Café, the sign said. Soon a hot chocolate, a pot of tea snuggled in a knitted cosy, and a frothy mocha jostled together on the chunky table. In the steamy warmth Maggie felt almost trapped in time, as if everything outside had speeded up while they were marooned on a 1950s island. Perhaps that was what made her think of her grandmother, Ethel, the teapot on a tray reminding her of cups and saucers and rich tea biscuits in bed, brought on a silver tray by a silver-haired, straightbacked old lady in a navy polka dot dress. Eve and Emily sat enthralled as Maggie told her granny's story: a young woman who lived in a big house with servants in the attic, and the man she wanted to marry against the wishes of her father.

'What did Granny’s family have against Clifford?' asked Eve.

'I don't know,' Maggie said. 'It must have been some bust up, when you think about it. They cut her out completely.'

In 2006 David Lodge expressed surprise at how popular biographical novels have become. Also described in academic literature as 'biofictions' (Lackey, 2016a, p. 3), these can be defined as fiction about a named, real person, and are characterised by creativity, invention, and imaginative exploration. The authors of such texts venture beyond the core postmodern argument that all textual representation is to some extent a creation by deliberately inventing 'stories that never occurred in order to answer perplexing questions, fill in cultural lacunae, signify human interiors, or picture cultural ideologies' (Lackey, 2016b, p. 14). Well-known examples of contemporary literary biofictions include In the Time of the Butterflies by Julia Alvarez (1994); Michael 
Cunningham's The Hours (1998); and Joyce Carol Oates's Blonde (1999). Biofiction is not confined to postmodernist innovation though: Max Saunders traces the roots of these ideas back through Modernist, fin de siècle, and late-Romantic works. He prefers the term 'autobiografiction' (Saunders, 2010, p. 7), which, he argues, complicates what at first might seem to be a straightforward relationship between Postmodernism and literary-biographical experimentation. Saunders's thesis holds that conflicting responses to life-writing, as well as helping to define the field, canon, and modes of interpretation of modern English literary history, have provoked new life-writing practices. These practices turn life-writing - biography and autobiography - into 'something different, something more like fiction' (Saunders, 2010, p. 9).

Why might we want to transform life-writing, through literary experimentation, into something more like fiction? One reason might be to smuggle vitality into the absences that seem to echo through the archives when it comes to women's lives. In a period when the majority of biography and formal autobiography concerned itself primarily with the lives of men, as Saunders observes, 'fiction paradoxically becomes an arena for granting female experience an equivalent reality in the public sphere' (Saunders, 2010, p. 10). No less of an issue today, it has been argued that elements of this formal, 'truth telling programme' (O’Brien, 1991, p. 125) of realist biography continue to hold strong sway in the standards to which contemporary biographical and autobiographical texts are held, while the battle for experimentation must be 'fought anew in every generation' (Cline and Angier, 2010, p. 58). The rewards, though, appear to be worth the struggle for feminist scholars and writers: to challenge the gendered assumptions associated with 'the linear development of a sovereign subject' (Novak, 2017, p. 6). In this way, as Novak argues, experimenting with genre can be read as a 'form of symbolic action' 
(Frow, 2006, p. 1-2). In this short essay I use a mixture of nonlinear narrative and theoretical writing to explore the argument that creative ways of responding to archival silences illuminate, and also complicate, our attempts to recover women's lives from obscurity. As the text evolves, the narrative sections become more invented, more experimental, something more like fiction.

'I think I've solved the mystery of Ethel's father!' Eve launched in as soon as she heard Maggie's voice on the phone.

'Oh yes?'

'Yes. Have you looked at the Southall divorce documents? I think they explain what he had against Clifford.'

Maggie had skimmed through when she added them to Clifford's parents' Ancestry profiles. The phrase that had stuck in her mind was 'a man of violent and ungovernable temper and intemperate habits'.

She sat down at her desk and switched on her computer, sipping her tea as she waited for the website to load. She didn't get any sense of Clifford's mother, Tishie, from these glimpses of her life through the straight-edged windows of census documents and parish records. Born Emma Jane Kentish - which must be the source of her nickname - in 1858, Tishie's childhood home was a substantial red brick house in Church Road, Moseley, a Victorian version of a commuter village about two miles south of the busy, smoky whirl of Birmingham. At some point before the 1871 census the Southall family moved in next door: Horatio, his wife Caroline, their three children, and two servants. The eldest son, Horatio William, was a solicitor like his father. Four 
years after that census, on 31st March 1875, Tishie and Horatio William were married at St Mary's Church, Moseley. She was 17, and he was 27. Their son, yet another Horatio, was born when Tishie was 19. The births of their daughter, Gladys, and their second son, Clifford - Ethel's Clifford - followed five and eight years later.

The documents reminded Maggie of the sort of zoetrope Tishie might have played with during her middle class Victorian childhood. She could use them to sketch out a series of frames in stale legal language - adultery and debts, a husband's violence and the humiliations he visited upon his wife - and then set them spinning until a jerky animation played to a whirring soundtrack.

Their house was built in the Arts and Crafts style, from what Maggie could tell online. Red brick topped by a tiled roof that ended its slope with an outwards flick, like a bell. Three small cottage style windows punctuated the upper frontage above an ornately latticed front door framed with thick white stonework, like the pillars and swirling icing on a wedding cake. Maggie had no way of knowing what their house was like inside, but she found herself swept up in the idea that they would have remained true to the aesthetic principles that informed the exterior: chalky, muted colours, natural materials, and simple floral motifs rather than the heavy, dark clutter of the more traditional Victorian home. As she added the layers of embroidery that brought colour to the white squares of the documents, Maggie imagined Tishie and Horatio William in their parlour, the walls behind the fireplace panelled with glowing rectangles of midbrown oak, flanked with shelves from the same wood, groaning with leather bound volumes. On the floor a rug, woven in a pattern of flowers twining around a diamond of faded red, the homely airiness of the décor incongruous with the heavy, dark, and cluttered atmosphere as Horatio William slid his silver letter opener into a handaddressed envelope. Inside was a letter from Mrs Benion asking for the repayment of a 
sum of $£ 2$, which she had advanced some weeks before. The letter prompted a fierce argument, during which Tishie called her husband a scamp, a rogue, a thief, and a liar, and then hurled a boot at him, which struck him on the head.

$* * *$

In June 2017 I presented a paper at the Centre for Life History and Life-writing Research conference, Critical and Creative Approaches, in which I explored the process of creating an autofictional character. I read extracts from a novel-in-progress about Ethel, my great-grandmother, and the autofictional character herself, Eve, and I posed some straightforward questions about ethics and representation. During the discussion a doctoral student raised her hand. Are you saying, she asked, that I can simply create the internal narrative of the historical figure I'm researching? Forty sets of eyes turned to me, expectantly.

If life-writing should be judged according to conventional, realist criteria, then my answer to that student has to be emphatically no. But if, as I have outlined in a previous section, we accept the legitimacy and value of thinking differently about life-writing, then how might we assess the quality, the ethics, the aesthetic and historical value of these experimental texts? How to decide if a particular biofictional representation is an unethical 'misappropriated life' - a particularly unfortunate outcome if the life itself is already just a few curling archival scraps - or whether it is a valuable ' $b$ ' (Lackey, 2016, p. 229)? 
It's tempting to turn to the comfortable domain of extensive and detailed research and seek reassurance there. Well, naturally the research must be beyond reproach, but there can be pitfalls: Barbara Mujica, who has herself written biographical novels about Diego Velazquez, Saint Teresa of Ávila, and Frida Kahlo, cautions that facts 'can overpower your characters and drain them of their vitality' (2016, p. 12). Which rather defeats the point of this kind of experimentation. So, whether a writer has produced a truthful fiction - rather than exploited a stolen identity - then, seems to come down to, in the simplest of terms, the skill, sensitivity, keen historical awareness and interpretive abilities of the writer to convey some sense of 'realness' without undermining what has been called the 'pact' that the writer will tell the truth (Lejeune, 1989; Kacandes, 2012). This argument is similar to that of Jeanette Winterson, who wrote, in the context of how much fiction might be based on the author's own experience: 'The fiction, the poem, is not a version of the facts, it is an entirely different way of seeing' $(2013, \mathrm{p}$. 28). The goal, then, is to "persuade through the communicative forces of fantasy... to spin magic that engrosses and convinces the reader' (Vargas Llosa, trans Mujica p. 12).

At the conference in Sussex I answered the student with caution. I don't think we should 'make up' the thoughts and feelings of our subjects and call it history. I think that whenever we produce work, whether scholarly or creative, we offer it up to judgement by peers and readers, and we have to be clear about what sort of claims we make for it. If I'd had Lackey's book on the table in front of me, I might have quoted directly from that text, advising us all to consider whether the author has 'done the necessary work' and if they have demonstrated the ability to 'fulfil the mandates of their implicit truth contract?' (Lackey, 2016, p. 254). 
The walls around the pale fireplace bloomed with William Morris' Daisy print; morning light from the small window fell on a box of books on the table beside a small, periwinkle seat. The only thing that jarred was the bed where Tishie sat in her nightgown, reading. A solid four-poster, made up with soft pillows and counterpane in delicate shades of summer skies to match the walls, ornate pillars carved from a wood so dark it appeared almost black, a relic of an earlier time.

Horatio William stormed into the room and caught sight of her sitting, content. He picked up the chamber pot in both hands, and tipped it over her head. For a moment she froze, cold ammonia-scented liquid trickling down her face, dripping from her hair. Then she threw her damp bedcovers aside and flew across the room, teeth bared.

'Stay away from me woman,' he said, dodging her with a cruel smirk, 'until you have taken a bath.'

'A bath!' Tishie raised her fists to strike. Horatio William grabbed her wrists, one in each hand, and held her away, squeezing hard enough to bruise, twisting one arm until Tishie cried out in a mixture of pain and frustration.

'I wish you were dead!' her voice cracked. 'If you were dying in the gutter I would not go across the road to help you!'

Horatio William tightened his hold on Tishie's wrists, straightening his arms to force some space between them before loosening his grip, only for her to try to strike him again. He hit out first, catching her a blow on the upper arm and knocking her to the floor where she remained, kneeling, still dripping with stale urine, fists clenched. 
'Dad,' came a shocked voice. Horatio William turned to find his adult son standing outside the open door, the young man's expression making his contempt perfectly clear. 'Very few men would strike a woman like that!'

'Very few men must put up with such a woman. And one who neglects her most basic natural duty to her husband. It is a wonder that any man in such a marriage doesn't seek to fulfil his needs elsewhere.'

'Why don't you then?' screamed Tishie. 'Just go, go away from me and my children, go with any woman you please. Just leave us in peace.'

According to the divorce documents, Horatio William took Tishie's words, reproduced above, as conducive to his adultery with a woman named Alice Bembridge, of 4 Grosvenor Road in the parish of Houndsworth. On that basis, he asked the court that Tishie's petition for divorce be dismissed.

The 1901 census shows Alice Bembridge of 4 Grosvenor Road in the parish of Houndsworth was 28 years old, and lived with her two sisters: Martha, a dressmaker, and Rebecca, a Lacquerware worker. Alice was recorded as the head of that household; her occupation 'lets apartments'. Her father, Nicholas Bembridge, at that time was 53, lived in Balsall Heath, and was employed as a photographer. Horatio William was a year younger than Alice's father, and was living separately from Tishie and his children, in a boarding house in the parish of St Jude, along with the landlord, Richard Bradshaw, and 17 other boarders. I was curious to imagine why a 28-year-old woman of apparently independent means would be interested in a relationship with a man more than twenty 
years her senior, a bankrupt with a string of failed business ventures (Birmingham Daily Post, 1887), embroiled in an embarrassing marital situation.

The 'character' of Alice Bembridge could be written as a calculating Madam (if the profession of 'letting apartments' were to be interpreted euphemistically). But what would such a person gain from a relationship with Horatio William in his present circumstances? This version of Alice might be playing the long game, encouraged by Horatio William to believe that he'd win his case in the High Court and gain his requested relief from Tishie who, by 1901, was the owner of nine houses in Pershore Road. This Alice might also have an eye to the circumstances of Horatio William's father-in-law (William Kentish was a wealthy man: when he died in 1913 he left s£28,094 3s 6d - about $£ 3$ million today, according to the Bank of England's online inflation calculator). But that version of a long game seems like a long shot, and couching a story in these terms a breach of the implied truth contract. What seems more possible is that at 52, Horatio William, who was, from documented accounts, a handsome and charismatic man, was attractive, and Alice simply fell for him.

Dear God. When she looked at him properly, in daylight, he wasn't even that handsome. The little wet snuffles increased in volume until a snore caught in his throat and he coughed, foetid stale whiskey breath washing over her. He was not handsome at all in fact. Dear God. And his wife had given them her blessing. Or at least, that's what he shouted as he lurched up the narrow staircase last night, deaf to her pleas to lower his voice, to have a care for her sisters, their neighbours. Dear God. 
This stooped paunchy brute who hawked in his throat and scratched his balls was nothing like the powerful, untouchable businessman with his starched white collars and silk cravats, whose hair glowed in flickering lights as he threw back his head with laughter and charmed his investors with promises of high returns. He was the most sophisticated man she'd ever met. Named for the Admiral, he'd say, and call her Lady Hamilton as he knelt to run his hands up the silk stockings he'd bought.

This shuffling stranger with unkempt moustaches and white hairs sprouting on his cheeks had snatched away the man who'd consumed her, whose cologne she'd splashed on her sheets so she could inhale his memory in the morning. She resented the deception bitterly, but not as much as she begrudged his continued presence.

Horatio William didn’t ask to stay with Alice and her sisters, he simply didn't leave. She needn't have worried about her neighbours or tenants because no one saw him. He only ever had one visitor, his solicitor, Mr Gough, a compact closed-in pinstriped man who would bring sheaves of papers covered in copperplate script. Papers Horatio William would seize and scrutinise until the early hours of the morning, grunting and muttering odd phrases as he scored the paper with red ink. 'Cruelty! Cruelty be dammed' and 'kicked, kicked? Ridiculous.'

He lost his case in the High Court. He lost his assets and custody of his two younger children. Worse than that it was all over the national newspapers, even quoting his eldest son's testimony against him. But worse still, much worse, was the papers naming Alice herself. 'How could you, how could you let this happen?' she sobbed, her face buried in print-smudged hands.

The despised creature lifted its greying dishevelled head and bellowed, 'It's you that's brought this misfortune to my door. Adultery with Alice Bembridge, isn't that your name, hmm? The reason they sided with that... woman?' He swiped at her head 
with the newspaper, the thick fold catching the corner of her eye. A trickle of red oozed down, a single furious tear. It would be the only one she shed for him.

\section{Acknowledgements}

Thanks are due to Eve Wedderburn for insightful comments on drafts of this article.

\section{References}

“1901 England Census" [database on-line]. Provo, UT, USA: Ancestry.com Operations Inc, 2005. Class: RG13; Piece: 2712; Folio: 82; Pages: 5, 41, 1.

Birmingham Daily Post. 1887. Monday May 9, 1887 (p. 6); Wednesday August 31887 (p. 6); Tuesday October 41887 (p. 6).

"Civil Divorce Records". The National Archives of the UK; Kew, Surrey, England; Class: J 77; Piece: 719. Ancestry.com. England \& Wales, 1858-1916 [database on-line]. Provo, UT, USA: Ancestry.com Operations, Inc., 2012. (p. 83).

Cline, Sally, and Carole Angier. 2010. The Arvon Book of Life Writing: Writing Biography, Autobiography and Memoir. London: Methuen Drama.

Collins, Katherine. 2017. "The fiction in truth: creating an autobiographical character" Paper." Paper presented at the 9th annual Brighton-Sussex postgraduate conference at the University of Sussex, 16 June.

Frow, John. 2006. Genre, The New Critical Idiom. London: Routledge.

Kacandes, Irene. 2012."Experimental Life-Writing," in The Routledge Companion to Experimental Literature, ed. Joe Bray, Alison Gibbons, and Brian McHale London: Routledge.

Lackey, Michael. 2016a. "Locating and Defining the Bio in Biofiction", $a / b$ : Auto/Biography Studies, 31:1, 3-10. 
Lackey, Michael. 2016b. The American Biographical Novel. London: Bloomsbury.

Lejeune, Philippe. 1989. On Autobiography. Minneapolis: University of Minnesota Press.

Lodge, David. "The author's curse”, Guardian, 20 May 2006 https:/www.theguardian.com/books/2006/may/20/featuresreviews.guardianrevie w2 [accessed 1 August 2018].

Mujica, Barbara. 2016. "Going for the Subjective: One way to Write Biographical Fiction", a/b: Auto/Biography Studies, 31:1, 11-20.

Novak, Julia. 2017. “Experiments in Life-Writing: Introduction”, in: Experiments in Life-Writing. Palgrave Studies in Life Writing. Eds. Boldrini L., Novak J. London: Palgrave Macmillan. 1-36.

O’Brien, Sharon. 1991. "Feminist Theory and Literary Biography," in Contesting the Subject: Essays in the Postmodern Theory and Practice of Biography and Biographical Criticism, ed. William H. Epstein. West Lafayette: Purdue University Press. 123-133.

"Rate Books". Textual records. Library of Birmingham, Birmingham, England. Ancestry.com. Birmingham, England, Rate Books, 1831-1913 [database online]. Provo, UT, USA: Ancestry.com Operations, Inc., 2014.

Saunders, Max. 2010. Self impression: Life-writing, autobiografiction, and the forms of modern literature. Oxford University Press.

Vargas Llosa, Mario. 1999. La verdad de las mentiras [The Truth of Lies]. Barcelona: Seix Barral, quoted in Barbara Mujica (p. 12).

Winterson, Jeanette. 2013. Art objects: Essays on ecstasy and effrontery. London: Random House. 
Dr Katherine Collins has held research posts at UWE and Goldsmiths College, and is currently working on the Andrew W. Mellon-funded Humanities \& Identities project at TORCH. Her research interests include the creative and critical practices involved in the writing of marginalised and activist lives, issues like the politics and poetics of lifewriting, testimonial cultures and witnessing, and autobiographies of resistance.

She is currently researching a biography of three activists - Paulo Freire, Orlando FalsBorda, and Muhammad Anisur Rahman - with particular attention to the ways in which their lived experiences of activist education and scholarship informed their theoretical contributions. From 2019 she will take up a post as a Leverhulme Early Career Fellow at Oxford's Department of Education. 